\title{
Chitosan Effects on Blackmold Rot and Pathogenic Factors Produced by Alternaria alternata in Postharvest Tomatoes
}

\author{
M.V. Bhaskara Reddy, Paul Angers, Francois Castaigne, and Joseph Arul ${ }^{1}$ \\ Department of Food Science and Nutrition, and Horticultural Research Center, Laval University, Sainte- \\ Foy, Quebec, Canada G1K 7 P4
}

AdDitional INDEX wORDs. Lycopersicon esculentum, macerating enzymes, organic acids, phytoalexin

\begin{abstract}
Aвstract. Stem scar application of chitosan inhibited growth and production of pathogenic factors by blackmold rot [Alternaria alternata (Fr.:Fr.) Keissl.] in challenged tomato (Lycopersicon esculentum Mill.) fruit stored at $20{ }^{\circ} \mathrm{C}$ for 28 days. Blackmold lesions were visible within 4 days of inoculation in control fruit, compared with $>7$ days in chitosantreated fruit. Macerating enzyme activity (polygalacturonase, pectate lyase, and cellulase) in the tissue in the vicinity of the lesions was $\mathbf{5 0 \%}$ in chitosan-treated fruit compared with control fruit. Chitosan also inhibited production of oxalic and fumaric acids (chelating agents) and host-specific toxins such as alternariol and alternariol monomethylether by the fungus. The $\mathrm{pH}$ of the infected tissue decreased from 4.7 to 4.0 in the control fruit, the optimum for polygalacturonase activity, while the $\mathrm{pH}$ of chitosan-treated fruit remained at 4.6. In addition, chitosan also induced production of rishitin (a phytoalexin) in tomato tissue. Such chitosan-pathogen-host interactions may be exploited in the control of postharvest pathogens of fresh fruit and vegetables.
\end{abstract}

Alternaria alternata is a causal agent of blackmold rot of tomato (Lycopersicon esculentum) fruit, a disease frequently causing substantial postharvest losses. The occurrence of Alternaria Nees in a wide variety of fruit and vegetables under diverse conditions of cultivation, handling, and storage suggests that the losses caused by Alternaria are comparable to other mold genera such as Aspergillus P. Mich ex Link, Penicillium Link and Fusarium Link (Stinson et al., 1980). The fungus tends to proliferate in tomato fruit and other produce affected by sun scald, chilling injury, blossom-end rot, faulty blossom scars, and growth cracks (Pearson and Hall, 1975). The fungus grows well at low temperatures, and is associated with extensive spoilage of coldstored fruit and vegetables (Stinson et al., 1980).

Alternaria produces a number of toxins as pathogenicity factors, among them alternariol (AL) and alternariol monomethylether (AME) are major ones, since these are produced by most Alternaria species in large quantities (Heisler et al., 1980). Toxins of Alternaria have been detected as natural contaminants of tomato fruit and tomato products (Stack et al., 1985), apples [Malus sylvestris (L.) Mill var. domestica (Borkh) Mansf.] (Stinson et al., 1981) and olives (Olea europaea L.) (Visconti et al., 1986). In addition, the fungus also produces cell wall-degrading enzymes and organic acids (El-Shaieb and Malibari, 1995; Hirsch et al., 1995). It has been suggested that organic acids produced by pathogens can damage host tissues by lowering $\mathrm{pH}$ of the tissue and acting synergistically with pectic enzymes in the digestion of Ca-pectate (Margo et al., 1984). Control of blackmold rot of tomato can be achieved by pre- and postharvest antifungal treatments, since the fungus can infect the fruit in the field and become latent in green tomato, and resume growth as the fruit ripens. The use of fungicides on fruit needs

Received for publication 8 Dec. 1998. Accepted for publication 31 July 2000. We acknowledge financial support of the Natural Sciences and Engineering Research Council (NSERC) of Canada-Strategic Grants Program, and the Conseil de Recherches en Pêche et Agroalimentaire du Québec (CORPAQ). The cost of publishing this paper was defrayed in part by the payment of page charges. Under postal regulations, this paper therefore must be hereby marked advertisement solely to indicate this fact.

'Corresponding author; joseph.arul@aln.ulaval.ca. strict control due to potential health risks, and none of them are approved for postharvest use. Hence, there is a need to exploit natural antifungal substances and host defenses for the control of postharvest pathogens.

Chitosan ( $(3,1-4$, linked glucosamine polymer), the deacetylated form of chitin, has been shown to be antifungal against a wide range of fungi (El Ghaouth et al., 1992a). Chitosan induces chitinases in plant tissue (El Ghaouth et al., 1992b; Mauch et al., 1984), structural defense barriers in bell pepper fruit [Capsicum апnиит L. var. апnиит (Grossum Group)] (El Ghaouth et al., 1994), and elicits the production of phytoalexin in pea pods (Pisum sativum L.) (Kendra and Hadwiger, 1984). Chitosan coating of strawberries (Fragaria Xananassa Duchesne) and tomato fruit reduces the severity of infection by Botrytis cinerea (Pers.) Fr. (gray mold) and Rhizopus stolonifer (Ehrenb.) Fr. (Rhizopus rot) and delays ripening (El Ghaouth et al., 1991; El Ghaouth et al., 1992c). Chitosan interferes with macerating enzyme production in B. cinerea when applied to the stem scars of bell pepper fruit (El Ghaouth et al., 1997). Our previous results showed that chitosan affects growth, morphology, and toxin production by A. alternata (Reddy et al., 1998), and multiplication and secretion of macerating enzymes by Erwinia carotovora ssp. carotovora (Jones) Bergey et al. (bacterial soft rot), in inoculated potato tissue (Solanum tuberosum L.) (Reddy et al., 1997). These observations revealed that chitosan, in addition to its direct antimicrobial activity, also interferes with pathogenic factors and induces host defenses. We report herein the mechanisms of chitosan action in controlling the progress of blackmold rot in postharvest tomato fruit.

\section{Materials and Methods}

Materials. Shrimp shell chitosan was purchased from NovaChem Ltd. (Dartmouth, Nova Scotia, Canada) and ground into a fine powder. The purified chitosan was prepared by dissolving chitosan in $0.25 \mathrm{~mol} \cdot \mathrm{L}^{-1} \mathrm{HCl}$, and the undissolved particles were removed by centrifugation $\left(15 \mathrm{~min}\right.$ at $10,000 \mathrm{~g}_{\mathrm{n}}$ ). The solution was then neutralized with $2.5 \mathrm{~mol} \cdot \mathrm{L}^{-1} \mathrm{NaOH}$ to a $\mathrm{pH}$ of 8.0 to precipitate the chitosan. The precipitated chitosan was recovered 
by filtration and washed extensively with deionized water to remove salts, and subsequently lyophilized. Chitosan solution $\left(10 \mathrm{~g} \cdot \mathrm{L}^{-1}\right)$ was prepared by dissolving chitosan in $0.05 \mathrm{~mol} \mathrm{~L}^{-1} \mathrm{HCl}$ and $\mathrm{pH}$ was adjusted to 5.6. Mature green 'Trust' tomato fruit were harvested in the Spring 1997 from the greenhouse at Laval University and sorted for uniformity of size and absence of blemishes. Selected fruit were surface sterilized by immersion in $13 \mathrm{mmol} \cdot \mathrm{L}^{-1} \mathrm{NaOCl}$ for $3 \mathrm{~min}$, rinsed in sterile deionized water and dried in ambient air. The fruit were then randomly divided into 20 fruit lots. Alternaria alternata was isolated from infected tomato and cultures were maintained on potato dextrose agar (PDA) at $22{ }^{\circ} \mathrm{C}$. Spore suspensions were obtained by flooding cultures of 10 -d-old $A$. alternata with sterile distilled water containing $1 \mathrm{ml} \cdot \mathrm{L}^{-1}$ Tween 80 . Spore counts were determined with an haemacytometer, and the spore concentration was adjusted with sterile distilled water to $2.5 \times 10^{5}$ conidia $/ \mathrm{mL}$.

Control of BLACKMOLD ROT. Fruit stem scars were treated individually either with chitosan solution or sterile deionized water. On each stem scar, $400 \mu \mathrm{L}$ of chitosan solution $\left(10 \mathrm{~g} \cdot \mathrm{L}^{-1}\right)$ or sterile water was applied and were dried under ambient conditions for $1 \mathrm{~h}$. After air drying, fruit were wound-inoculated $1 \mathrm{~cm}$ away from the stem scar by pipetting $50 \mu \mathrm{L}$ of spore suspension and were subsequently placed on wire mesh platforms in plastic containers and stored in the dark at $20^{\circ} \mathrm{C}$. A layer of water was placed at the bottom of the container to maintain high humidity and containers were closed with perforated lids to eliminate any accumulation of $\mathrm{CO}_{2}$. Fruit were evaluated daily for lesions over a period of $28 \mathrm{~d}$, and pericarp tissue samples from the edge of the lesions were drawn at various storage intervals after inoculation for assaying cell walldegrading enzymes, toxins, and organic acids produced by the fungus and phytoalexin elicited by chitosan treatment. Disease severity of inoculated fruit was followed during storage in both control and chitosan-treated fruit in three replications, each replication consisting of five fruit stored in separate containers. For evaluating pathogenesis and disease resistance, there were 15 fruit for each treatment (inoculated and noninoculated controls, and inoculated and noninoculated chitosan treatment), and storage interval $(0,7,14,21$, or $28 \mathrm{~d})$. Analysis of enzyme activity and phytoalexin level were performed on separate lots of five fruit, while toxin and acid content as well as $\mathrm{pH}$ were determined on the same lot of five fruit. Fruit were arranged in a randomized complete block design, and the experiment was conducted twice. Data were pooled and analysis of variance was applied to the different experimental data (SAS Institute, 1988) and the standard error of the mean was determined. Means were compared using the Fisher's protected least significant difference (LSD) at $P<0.05$.

Tissue SAMPLES AND PH. Pericarp tissues were sampled from inoculated fruit by excising the tissue from the inoculation site up to 1 to $2 \mathrm{~cm}$ beyond the edge of the expanding lesion. Tissues were sampled from noninoculated fruit around the stem scar from the edge up to a span of 1.5 to $2.0 \mathrm{~cm}$. The $\mathrm{pH}$ of the tissue suspended in distilled water was measured using a pH meter (Model 50, Fisher Scientific, Montreal, Canada).

ENZYMe PREPARATION AND ASSAY. Pericarp tissue samples (3 g) were homogenized in $12 \mathrm{~mL}$ buffer solution $\left(10 \mathrm{mmol} \cdot \mathrm{L}^{-1}\right.$ PIPES buffer (pH 6.5) and $5 \mathrm{mmol} \cdot \mathrm{L}^{-1}$ thiourea) using a micromill (Bel-Art Products, Pequannock, N.J.) for $1 \mathrm{~min}$ and the homogenate was centrifuged at $20,000 g_{n}$ for $30 \mathrm{~min}$. The pellet was washed twice by redissolving it in $2 \mathrm{~mL}$ of the buffer solution and centrifuging at $20,000 g_{n}$ for $10 \mathrm{~min}$. The combined supernatants constituted the crude extract. All extraction procedures were performed at $4{ }^{\circ} \mathrm{C}$. Protein determinations were carried out according to the method of Bradford (1976).
The method of Ayers et al. (1966) was followed to determine polygalacturonase (PG) and pectate lyase (PL) activities. The reaction mixture consisted of $3 \mathrm{~mL} 10 \mathrm{~g} \cdot \mathrm{L}^{-1}$ polygalacturonic acid (Sigma Chemical Co., St. Louis, Mo.), $2.5 \mathrm{~mL} 0.1 \mathrm{~mol} \cdot \mathrm{L}^{-1} \mathrm{Tris} / \mathrm{HCl}$ $\mathrm{pH} 8.0,0.5 \mathrm{~mL}$ of enzyme extract, and $\mathrm{CaCl}_{2}$ adjusted to 0.8 $\mathrm{mmol} \cdot \mathrm{L}^{-1}$ in the mixture. The mixture was incubated at $30{ }^{\circ} \mathrm{C}$ for 4 $\mathrm{h}$, and the excess substrate and enzymes were precipitated by adding $0.6 \mathrm{~mL} 90 \mathrm{~g} \cdot \mathrm{L}^{-1} \quad \mathrm{ZnSO}_{4}$ and $0.6 \mathrm{~mL} 0.5 \mathrm{~mol} \cdot \mathrm{L}^{-1} \mathrm{NaOH}$. After vigorous mixing, the precipitate was sedimented by centrifugation at $30,000 \mathrm{~g}_{\mathrm{n}}$ for $10 \mathrm{~min}$. To $1 \mathrm{~mL}$ of the supernatant, $0.6 \mathrm{~mL} 0.04$ $\mathrm{mol} \cdot \mathrm{L}^{-1}$ thiobarbituric acid, $0.3 \mathrm{~mL} 1 \mathrm{~mol} \cdot \mathrm{L}^{-1} \mathrm{HCl}$ and $0.1 \mathrm{~mL}$ distilled water were added, and the mixture was heated in a boiling water bath for $30 \mathrm{~min}$ to develop the color. After cooling, the absorbance of the solutions were measured at $515 \mathrm{~nm}$ for PG and 550 $\mathrm{nm}$ for PL using a spectrophotometer (model 8451A; Hewlett Packard, Kirkland, Quebec, Canada).

Cellulase activity was determined using CM cellulose-RBB (remazol brilliant blue) as substrate (Wolf and Wirth, 1989). The reaction mixtures contained $0.3 \mathrm{~mL}\left(1 \mathrm{~g} \cdot \mathrm{L}^{-1}\right)$ substrate solution, 0.6 $\mathrm{mL} 0.1 \mathrm{~mol} \cdot \mathrm{L}^{-1}$ sodium acetate buffer $(\mathrm{pH} 4.8)$ and $0.3 \mathrm{~mL}$ crude extract. The reaction was terminated after $4 \mathrm{~h}$ at $25^{\circ} \mathrm{C}$ by adding 0.3 $\mathrm{mL} 0.5 \mathrm{~mol} \cdot \mathrm{L}^{-1} \mathrm{HCl}$. After cooling in an ice-water bath for $15 \mathrm{~min}$, the mixture was centrifuged at $14,000 g_{\mathrm{n}}$ for $5 \mathrm{~min}$ and the absorbance of the dye covalently linked to the degraded polysaccharide was measured at $600 \mathrm{~nm}$ using a spectrophotometer (model 8451A; Hewlett Packard).

Extraction of TOXins AND ORganic ACIDS. Pericarp tissue samples $(3 \mathrm{~g})$ were homogenized in methanol (1g of tissue : $3 \mathrm{~mL}$ of methanol) and centrifuged at $1,000 \mathrm{~g}_{\mathrm{n}}$ for $5 \mathrm{~min}$. The residue was reextracted twice in the same manner and the $\mathrm{pH}$ of the combined supernatants was adjusted to 8.0 with $1.27 \mathrm{~mol} \cdot \mathrm{L}^{-1} \mathrm{NH}_{4} \mathrm{HCO}_{3}$. An equivalent volume of water was added to the extract and the aliquot was extracted twice with $200 \mathrm{~mL}$ of chloroform each time. The combined chloroform extracts were reduced in volume to $\approx 80 \mathrm{~mL}$ under vacuum $(8.93 \mathrm{kPa})$ and dried overnight over anhydrous $\mathrm{Na}_{2} \mathrm{SO}_{4}$. The filtered extract was dried completely under reduced pressure before derivatization for toxin analysis. Organic acids were extracted from the water extract. The samples were dried overnight over anhydrous $\mathrm{Na}_{2} \mathrm{SO}_{4}$ and partitioned twice with diethyl ether $(10 \mathrm{~mL}$ followed by $5 \mathrm{~mL})$. The samples were evaporated under nitrogen and subsequently transferred to analytical glass vials and further evaporated to dryness under nitrogen. Both dried fractions for toxins and organic acids were derivatized by adding $100 \mu \mathrm{L}$ dimethyl formamide and $50 \mu \mathrm{L}$ of the reagent methyl tert-butyl silyl trifluoroacetamide (MTBSTFA) and the reaction mixture was incubated at $65^{\circ} \mathrm{C}$ for $2 \mathrm{~h}$ before analysis by gas chromatography (GC).

Extraction of Phytoalexins. Pericarp tissue samples (10 g) were homogenized in methanol ( $1 \mathrm{~g}$ of tissue : $3 \mathrm{~mL}$ methanol) and centrifuged at $1,000 g_{\mathrm{n}}$ for $5 \mathrm{~min}$ (Hildenbrand and Ninnemann, 1994). The residue was reextracted twice in the same manner and the combined supernatants were dried under vacuum at $40{ }^{\circ} \mathrm{C}$. The residue was dissolved in $100 \mathrm{~mL}$ aqueous methanol $\left(14.8 \mathrm{~mol} \cdot \mathrm{L}^{-1}\right)$ and partitioned three times with $100 \mathrm{~mL}$ chloroform, allowing the phases to separate for $1 \mathrm{~h}$. The combined chloroform fractions were reduced in volume to $\approx 80 \mathrm{~mL}$ under vacuum and dried overnight by adding anhydrous $\mathrm{Na}_{2} \mathrm{SO}_{4}$. The filtered extract was evaporated under reduced pressure and redissolved in $1.5 \mathrm{~mL}$ dichloromethane. The samples were transferred to analytical glass vials, evaporated further under nitrogen, and derivatized before analysis by GC.

Gas Chromatography. Alternariol, AME, oxalic and fumaric acids, and rishitin were assayed by GC (model 5890; Hewlett 
Table 1. Blackmold rot development in chitosan-treated and control tomato fruit.

\begin{tabular}{lcccc}
\hline & \multicolumn{4}{c}{ Days after inoculation } \\
\cline { 2 - 5 } Treatment & 7 & 14 & 21 & 28 \\
\hline \multirow{2}{*}{ Water control } & $0.9 \pm 0.2$ & $4.2 \pm 0.9$ & $8.3 \pm 1.5$ & $10.6 \pm 2.0$ \\
Chitosan & $0 \pm 0$ & $2.1 \pm 0.4$ & $3.3 \pm 0.6$ & $3.8 \pm 0.7$ \\
\hline
\end{tabular}

${ }^{\mathrm{Z}}$ Each value represents the mean of four samples per treatment \pm SE.

Packard, Avondale, Pa) equipped with a flame ionization detector. The chromatographic separation was carried out on a capillary column (model DB5-30M; Hewlett Packard, ) $0.25 \mathrm{~mm}$ i.d. $\times 30 \mathrm{~m}$ long and $0.25 \mu \mathrm{m}$ film thickness. Hydrogen was used as the carrier gas at a linear velocity of $35.5 \mathrm{~cm} \cdot \mathrm{s}^{-1}$ at $200{ }^{\circ} \mathrm{C}$. The detector temperature was $325^{\circ} \mathrm{C}$, and the injector temperature was $300^{\circ} \mathrm{C}$. The oven temperature was programmed from $150^{\circ} \mathrm{C}$ for $2 \mathrm{~min}$, then to $300{ }^{\circ} \mathrm{C}$ at $5^{\circ} \mathrm{C} \cdot \mathrm{min}^{-1}$, and held at $300^{\circ} \mathrm{C}$ for $5 \mathrm{~min}$. The injections were performed with an auto sampler (model 7673; HewlettPackard). The data were processed using Hewlett Packard HP3365 software. Under these conditions, the order of elution was oxalic and fumaric acids, AME, rishitin and AL. Standards of toxins and organic acids were used for identification (Sigma), while rishitin was identified by comparing with the standard obtained from Susan McCormick, National Center for Agricultural Utilization Research (NCAUR), U.S. Dept. of Agriculture, Agricultural Research Service, Peoria, Ill.

\section{Results}

EFFeCt of Chitosan ON BLACKMOLD ROT DEVELOPMENT. Blackmold rot developed at a higher rate $(P<0.05)$ in the inoculated control fruit compared with chitosan-treated fruit (Table 1). In the inoculated control fruit, lesions were visible within $4 \mathrm{~d}$ after inoculation and increased significantly with storage time, while in the chitosan-treated fruit, lesions were visible only after $7 \mathrm{~d}$ of storage. The size of the lesion in chitosan-treated fruit was less than one fourth of the fruit surface after $28 \mathrm{~d}$ of storage compared with total rot of the fruit in the control lot. Control of lesion development in chitosan-treated fruit indicates that chitosan had an inhibitory effect on pathogenic factors of A. alternata.

MACERATING ENZYMES. Analysis of macerating enzymatic activity in extracts of tissue around the lesions in both chitosan and nonchitosan-treated fruit challenged with the pathogen showed lower activities $(P<0.05)$ of polygalacturonase, pectate lyase, and cellulase in chitosan-treated fruit compared with inoculated control fruit (Fig. 1). Among the enzymes, polygalacturonase activity was the highest in the infected tissue followed by pectate lyase and cellulase in both inoculated control and chitosan-treated fruit. Maximum polygalacturonase activity was recorded after $21 \mathrm{~d}$ of storage, followed by a decline. Maximum cellulase activity was recorded at $14 \mathrm{~d}$ of storage. In general, the activities of all cell wall-degrading enzymes remained $50 \%$ lower in chitosan-treated fruit compared with inoculated control fruit.

ORGANIC ACIDS. Oxalic and fumaric acid production by A. alternata increased with storage in both control as well as chitosantreated fruit challenged with the pathogen
(Fig. 2). However, the levels of acids were lower $(P<0.05)$ in chitosan-treated fruit compared with control fruit. Oxalic acid level was higher in both tissues compared with fumaric acid throughout the storage period. Only small amounts of oxalic acid $\left(12 \mathrm{mg} \cdot \mathrm{g}^{-1}\right)$ and fumaric acid $\left(8 \mathrm{mg} \cdot \mathrm{g}^{-1}\right)$ were detected in healthy tomato tissue up to a period of $14 \mathrm{~d}$. After $28 \mathrm{~d}$ storage, the amount of oxalic acid produced by the fungus in chitosan-treated fruit was $<25 \%$ of the quantity produced in the control fruit, but the inhibition was relatively small for fumaric acid. The levels of both acids increased and the $\mathrm{pH}$ of the tissue decreased in the inoculated control fruit throughout the storage period. The $\mathrm{pH}$ decreased from 4.7 to 4.0 from day 7 to day 28 in the inoculated control, but it remained at $\approx 4.6$ in chitosan treated fruit (Fig. 3). In healthy fruit, only a slight decrease in $\mathrm{pH}$ was noticed from day 7 to day 28 . These results show that organic acids secreted by the fungus in inoculated control fruit decreased the tissue $\mathrm{pH}$ to 4.0 which is optimum for PG activity. Enzymatic activities in tissue extracts from inoculated control fruit were tested in vitro at $\mathrm{pH}$ ranging from 4.0 to 4 .7. The activities were not significantly different in this $\mathrm{pH}$ range, indicating that this narrow decrease in $\mathrm{pH}$ at the site of infection may not have an influence on enzymatic activity.

HosT SPECIFIC TOXINS. Chitosan treatment of tomato fruit also interfered with production of toxins by the fungus. Although the toxin concentration of tissue increased from day 7 to day 28 in both chitosan-treated and control fruit challenged with the pathogen, it was lower $(P<0.05)$ in chitosan-treated fruit. Alternariol content varied from 1 to $2.3 \mathrm{mg} \cdot \mathrm{g}^{-1}$ of infected tissue in the controls compared with 0 to $1.3 \mathrm{mg} \cdot \mathrm{g}^{-1}$ in chitosan-treated fruit from day 7 to day 28 (Fig. 4A). A similar trend was observed in the alternariol monomethylether content of the infected tissue (Fig. 4B).

Phytodenexin. Chitosan treatment also induced production of rishitin, a sesquiterpenoid phytoalexin of tomato (Fig. 5). The highest amounts of rishitin were present in chitosan-treated fruit challenged with the pathogen. In both chitosan-treated and control fruit challenged with the pathogen, rishitin levels increased up to 21 $\mathrm{d}$ of storage beyond which it decreased. Rishitin concentration was higher $(P<0.05)$ in chitosan-treated fruit as well as fruit challenged with the pathogen following chitosan treatment compared with inoculated control fruit. Rishitin concentration continued to increase in chitosan-treated fruit challenged with the pathogen up to $21 \mathrm{~d}$ after treatment.

Fig. 1. Changes in the activities of macerating enzymes in tomato fruit treated with (O) or without $(\bigcirc)$ chitosan, and challenged with A. alternata. (A) Polygalacturonase, $(\mathbf{B})$ pectate lyase, and $(\mathbf{C})$ cellulase. Vertical bars represent SES of five samples per treatment.

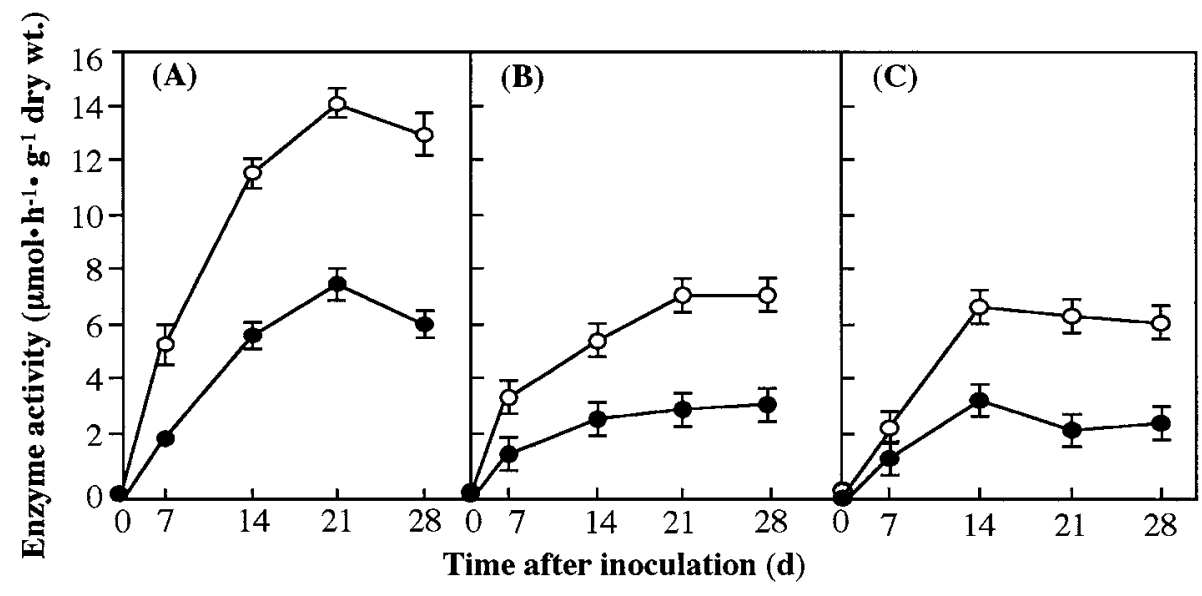




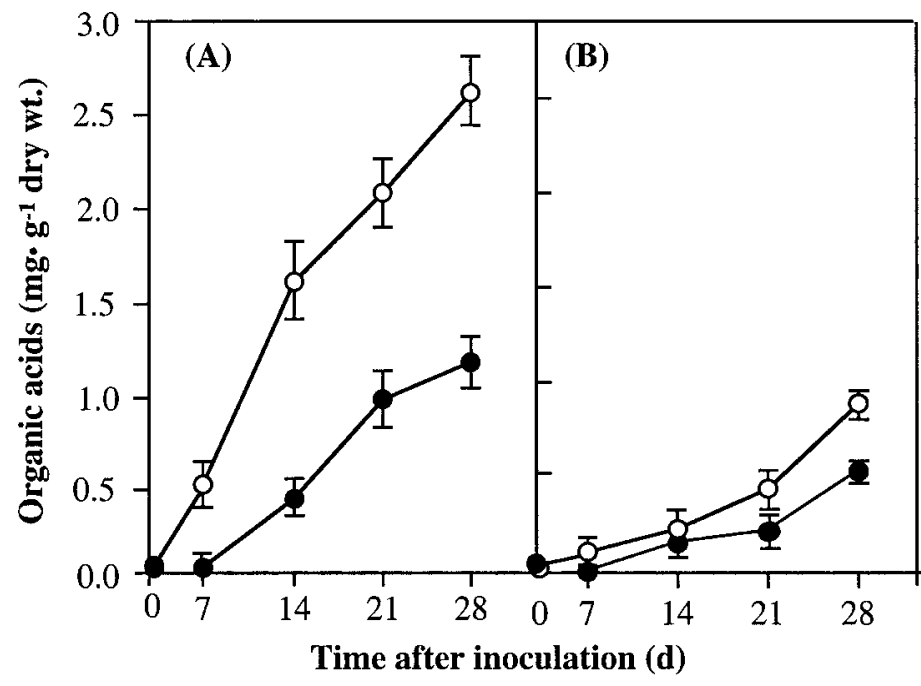

Fig. 2. Changes in (A) oxalic acid and (B) fumaric acid content in tomato fruit treated with (O) or without $(\bigcirc)$ chitosan, and challenged with A. alternata. Vertical bars represent SES of five samples per treatment.

\section{Discussion}

Stem scar application of chitosan to tomato fruit inhibited the progress of blackmold rot by restricting growth and secretion of pathogenic factors by A. alternata. Inhibition of fungal growth as evidenced by reduced lesion size in chitosan treatments shows that chitosan was directly antifungal. In addition, chitosan interfered with production of fungal virulence factors such as cell wall degrading enzymes, organic acids, and host specific toxins. Several studies have confirmed direct antifungal action of chitosan (Allan and Hadwiger, 1979; El Ghaouth et al., 1991, 1992a ). Although information is available on the antimicrobial effects of chitosan, it is imperative to know the actual mechanism and its interference in pathogenesis of disease causing organisms in plants. Our previous studies showed that chitosan treatment at sublethal concentrations interferes with production of host specific toxins such as AL and AME by A. alternata more than the fungal biomass (Reddy et al., 1998) and macerating enzymes by E. carotovora in potato (Reddy et al., 1997). Many studies have confirmed the antimicrobial effect of chitosan when it is in direct contact with the target organism. In the present study, we inoculated the pathogen at sites adjacent to treated stem scars of the fruit in order to gain some understanding of any systemic action of chitosan, and observed inhibition of the pathogen growth even though the sites of chitosan treatment and inoculation were not the same. This suggests that chitosan acts in some systemic manner which involves either a direct effect or induction of defense reactions in the host. This is possible by translocation of chitosan oligosaccharides by enzymatic cleavage of chitosan polymer and/or by a mechanism involving signal transduction. Chitosan is unusually susceptible to a variety of enzymes such as proteases, cellulases, pectic enzymes, and lipases (Pantaleone et al., 1992). It is then possible that the applied chitosan polymer is cleaved by plant enzymes when in contact with the tissue; and chitosan oligosaccharides translocate from the application site to the neighboring cells, and inhibit fungal growth at sites away from the site of application. This hypothesis is supported by the observation of Hadwiger and Beckman (1980) that chitosan accumulates in plant cells adjacent to the sites of chitosan treatment in pea podFusarium solani interactions. The second scenario may also be at work. We detected rishitin at sites away from the stem scar where chitosan was applied. Since phytoalexins cannot translocate but their signals can (Kuc, 1987), we hypothesize that rishitin accumulation elsewhere than the site of treatment is mediated by signal molecules. The finding of Doares et al. (1995) that chitosan oligosaccharides activate plant defense genes by signal transduction involving jasmonic acid similar to wound response, sustains this hypothesis.

Secretion of cell-wall degrading enzymes, organic acids, and host specific toxins have long been recognized to be of prime importance in necrotrophic pathogenesis (Ikotun, 1984 ; Schafer, 1994). Pectic substances play an important role in maintaining the architecture of plant cell walls. Depolymerization of pectin has been shown to be a prerequisite for degradation of other cell wall polymers (Bauer et al., 1977). Decreased enzymatic activity in chitosan-treated fruit at the infection site of the fungus suggests that chitosan treatment affected the capability of $A$. alternata to produce macerating enzymes. Bennett et al. (1993) showed that polygalacturonase-solubilized pectic fragments from tomato tissue may act as signal molecules which specifically induce toxin production of $A$. alternata. This can account for the increased toxin production in nonchitosan-treated fruit. On the other hand, in chitosan-treated fruit, the solubilization capacity of PG produced in the presence of chitosan could also be lower as was shown earlier with the potatoErwinia system (Reddy et al., 1997). Hence, the required signals to induce toxin production by the pathogen may not have been generated resulting in decreased virulence of the fungus. Cellulase activity was also observed, but was lower than PG and PL, and its activity was also inhibited by chitosan treatment.

Secretion of organic acids by the pathogens facilitates its rapid colonization of the tissue, and is a determinant in its virulence. Oxalic and fumaric acids can chelate calcium from the middle lamella of plant cell walls rendering pectic substances more susceptible for hydrolysis by pectolytic enzymes secreted by the fungus (Margo et al., 1984), and destabilizing the cell membranes causing

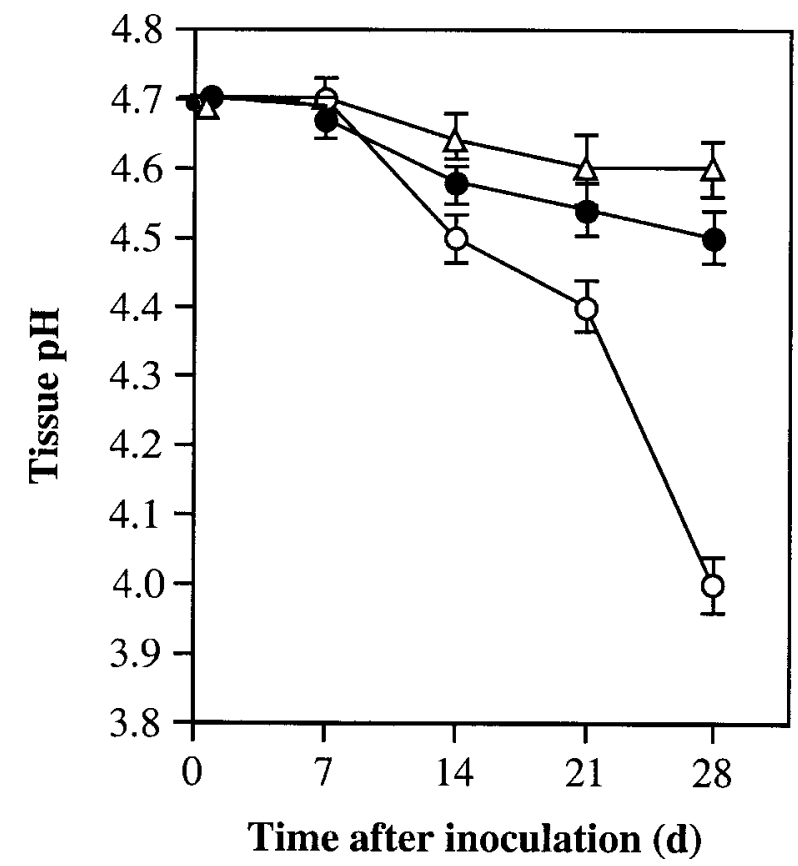

Fig. 3. Changes in $\mathrm{pH}$ of tomato fruit treated with $(-)$ or without $(\bigcirc)$ chitosan, and challenged with A. alternata. and in nontreated, noninoculated fruit (D). Vertical bars represent ses of five samples per treatment. 


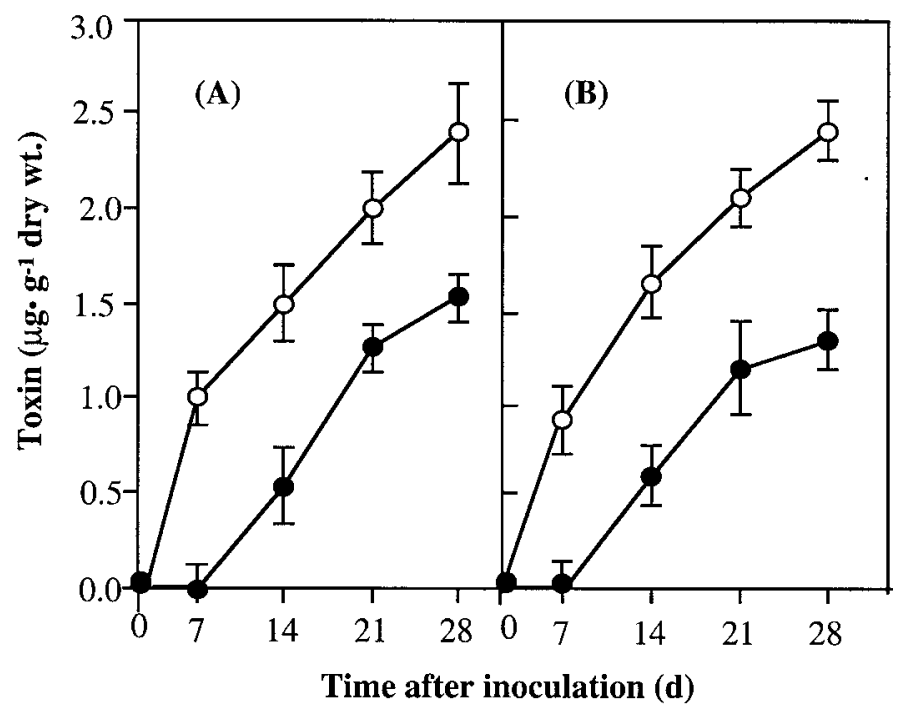

Fig. 4. Changes in phytotoxins in tomato fruit treated with $(\mathbf{O})$ or without $(\bigcirc)$ chitosan, and challenged with A. alternata. (A) Alternariol and (B) alternariol monomethylether. Vertical bars represent sEs of five samples per treatment.

cellular leakage (Pooviah, 1986). In addition, acidification of the tissue at the infection site would also tend to neutralize the inhibitory effect of tomatine, a preformed inhibitor in tomato. Tomatine is a weak base and exhibits maximum fungistatic activity in its nonionized form, while its protonated form is less effective. Fungi such as $B$. cinerea which are able to decrease the $\mathrm{pH}$ at the infection site are virulent, whereas those which increase the $\mathrm{pH}$ such as Monilia fructigena Pers.: Fr (brown rot fungus) are inhibited by tomatine (Schlösser, 1975). Thus higher production of organic acids in inoculated control fruit than in chitosan-treated fruit promotes rapid growth of the fungus in control fruit as indicated by the larger lesion size, and actively growing fungus produces more acids enabling it to colonize the tissue further. Bateman and Beer (1965) found a synergistic interaction between oxalate and polygalacturonase in Sclerotium rolfsii Sacc. infected plants which may account for the rapid collapse and death of infected tissue. A mixture of endopolygalacturonase and $25 \mathrm{mmol} \cdot \mathrm{L}^{-1}$ oxalic acid macerated and killed sweet potato [Ipomea batatus (L.) Lam.] tissue faster than either of them individually (Ikotun, 1984). Oxalic and fumaric acids act synergistically with cell wall degrading enzymes, especially pectolytic enzymes (Hancock, 1972; Ikotun, 1984; Maxwell and Lumsden, 1970). In the inoculated control, the tissue $\mathrm{pH}$ decreased to 4.0 from 4.7 within $14 \mathrm{~d}$ after inoculation presumably due to increases in oxalic and fumaric acid content. This would lead to protonation of pectic substances of the cell wall and may contribute to loosening of the wall, facilitating its digestion by cell wall degrading enzymes. Our study demonstrates that a lower level of organic acid production by the pathogen in the presence of chitosan, rendered the fungus less virulent. It would be interesting to see the capacity of the fungus to produce virulence factors with repetitive exposure to chitosan which could be used in evolving hypovirulent strains of the fungus.

Alternaria toxins are known to cause severe chlorosis and necrosis in plant tissue and plant flaccidity with limited water loss (Otani et al., 1995). Results herein demonstrate that lesion expansion and production of AL and AME by the fungus was inhibited by chitosan application concomitant to mycelial growth. However, the specific concentration of toxin was higher in infected tissue from inoculated control fruit compared with chitosan-treated fruit, indi- cating that chitosan, in addition to inhibiting fungal growth impaired the production of phytotoxic fungal metabolites by the fungus which is in agreement with our previous results (Reddy et al., 1998).

Chitosan treatment also enhanced production of rishitin, a major antifungal phytoalexin in tomato. Several studies have shown the ability of chitosan to induce host defenses. Chitosan treatment of potato slices protects the tissue against soft rot caused by $E$. carotovora by inducing rishitin and phytuberin (Reddy et al., unpublished). The reduction in the rishitin content after $21 \mathrm{~d}$ could be due to decreased capacity of the host to produce rishitin with progress of tissue ripening, or catabolism by the pathogen or even by the host, since they can also be toxic to the host (Darvill and Albersheim, 1984).

One trait that may potentially determine either pathogenicity or virulence towards a specific host is the ability of the fungus to tolerate fungistatic or toxic compounds produced by the host such as phytoalexins (VanEtten et al., 1989). Higher tolerance to the host phytoalexin is correlated to higher virulence on that host (Bowyer etal., 1995; Miao and VanEtten, 1992). Though rishitin was induced in response to infection in inoculated control fruit, the fungus grew without any inhibition due to either tolerance of the fungus to low concentrations of phytoalexin or delayed formation of phytoalexin, as is the case in many host-pathogen interactions which makes this defense less effective (Darvill and Albersheim, 1984). However, accumulation of phytoalexin induced by chitosan treatment before colonization of the tissue by the pathogen, could provide an advantage to the tissue in fighting the infection. Further accumulation of rishitin in chitosan-treated fruit in response to inoculation may reinforce the defense, thereby protecting the tissue. In addition to rishitin, involvement of preformed inhibitors such as tomatine present in high concentrations in the peel of green tomatoes can also contribute to the resistance (Swinburne, 1983), however it degrades with maturity of tissue. Tomatine can be detoxified by tomatinase produced by specific pathogens (Osburn et al., 1995), or rendered ineffective by acidification of the tissue by the pathogen (Schlösser, 1975). The early appearance and fast expansion of lesions observed

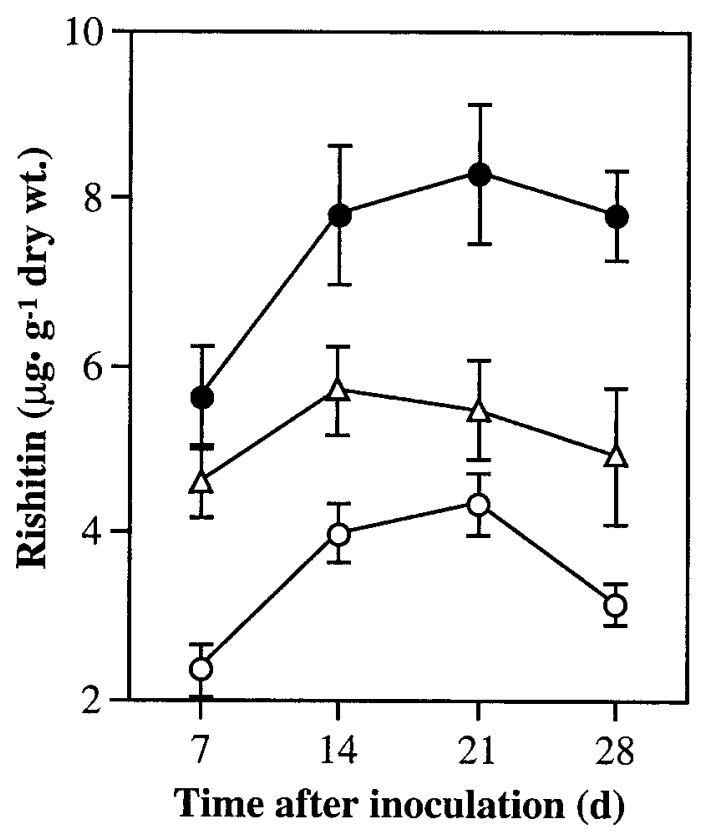

Fig. 5. Changes in rishitin content of tomato fruit treated with $(\bigcirc)$ or without $(\bigcirc)$ chitosan, and challenged with A. alternata, and in fruit treated with chitosan but noninoculated $(\Delta)$. Vertical bars represent SEs of five samples per treatment. 
in inoculated control fruit may be due to detoxification mechanisms adapted by the fast growing fungus. But with chitosan treatment the fungus remains quiescent or exhibits slower progress of infection due to either loss of virulence of the fungus or preformed antimicrobial substances, and induced antimicrobial compounds such as rishitin (Reddy et al., unpublished) and phenolic compounds (Dornenburg and Knorr, 1997; Pearce et al., 1998; Reddy et al., 1999) in the tissue.

In conclusion, the present investigation demonstrates that stem scar application of chitosan inhibits development of blackmold rot of tomatoes and reduces production of pathogenic factors by the fungus, such as cell wall-degrading enzymes, organic acids, and host specific toxins responsible for fungal penetration and host tissue damage. Chitosan also induces phytoalexin production in the host. Such interactions of chitosan with the pathogen and the host suggest that chitosan could be a useful natural material for postharvest preservation of fruit and vegetables.

\section{Literature Cited}

Allan, C.R. and L.A. Hadwiger. 1979. The fungicidal effect of chitosan on fungi of varying cell wall composition. Expt. Mycol. 3:285-287.

Ayers, W.A., G.C. Papavizas, and A.F. Diem. 1966. Polygalacturonate trans-eliminase and polygalacturonase production by Rhizoctonia solani. Phytopathology 56:10061011.

Bateman, D.F. and S.V.Beer. 1965. Simultaneous production and synergistic action of oxalic acid and polygalacturonase during pathogenesis by Sclerotium rolfsii. Phytopathology 55:204-211.

Bauer, W.D., D.F. Bateman, and C.H. Whalen. 1977. Purification of an endo- $\beta-1,4$ galactanase produced by Sclerotinia sclerotiorum: Effects on isolated plant cell walls and potato tissue. Phytopathology 82:1185-1193.

Bennett, A.B., R. Chetelat, E. Klann, C. Lasbrook, R. Martin, and D. Gilchrist. 1993. Physiologically-directed molecular and biochemical approaches to plant improvement. Trans. Malaysian Soc. Plant Physiol. 3:200-209.

Bowyer, P., B.R. Clarke, P. Lunness, M.J. Daniels, and A.E. Osburn. 1995. Host range of a plant pathogenic fungus determined by a saponin detoxifying enzyme. Science 267:371-374.

Bradford, M.M. 1976. A rapid and sensitive method for the quantification of microgram quantities of protein utilizing the principle of protein-dye binding. Anal. Biochem. 72:248-251.

Darvill, A.G. and P. Albersheim. 1984. Phytoalexins and their elicitors: A defense against microbial infection in plants. Annu. Rev. Plant Physiol. 35:243-275.

Doares, S.H., T. Syrovets, E.W. Weiler, and C.A. Ryan. 1995. Oligogalacturonides and chitosan activate plant defensive genes through the octadecanoid pathway. Proc. Natl. Acad. Sci. USA 92:4095-4098.

Dornenburg, H. and D. Knorr. 1997. Evaluation of elicitor-and high-pressure-induced enzymatic browning utilizing potato (Solanum tuberosum) suspension cultures as a model system for plant tissues. J. Agr. Food Chem. 45:4173-4177.

El Ghaouth, A., J. Arul, A. Asselin, and N. Benhamou. 1992a. Antifungal activity of chitosan on post harvest pathogens: Induction of morphological and cytological alterations in Rhizopus stolonifer. Mycol. Res. 96:769-779.

El Ghaouth, A., J. Arul, J. Grenier, and A. Asselin. 1992b. Antifungal activity of chitosan on two post harvest pathogens of strawberry fruits. Phytopathology 82:398-402.

El Ghaouth, A., J. Arul, R. Ponnampalam, and M. Boulet. 1991. Chitosan coating effect on storability and quality of fresh strawberries. J. Food Sci. 56:1618-1620.

El Ghaouth, A., J. Arul, C. Wilson, and N. Benhamou. 1994. Ultrastructural and cytochemical aspects of the effect of chitosan on decay of bell pepper fruit. Physiol. Mol Plant Pathol. 44:417-432.

El Ghaouth, A., J. Arul, C. Wilson, and N. Benhamou. 1997. Biochemical and cytochemical aspects of the interaction of chitosan and Botrytis cinerea in bell pepper fruit. Postharvest Biol. Technol. 12:183-194.

El Ghaouth, A., R. Ponnampalam, F. Castaigne, and J. Arul. 1992c. Chitosan coating to extend the storage life of tomatoes. HortScience 27:1016-1018.

El-Shaieb, M.K.Z. and A.A. Malibari. 1995. Enzymatic activities of soft rot causal organisms affecting vegetables and fruits in Saudi Arabia. Alex. J. Agr. Res. 40:293304.

Hadwiger, L.A. and J.M. Beckman. 1980. Chitosan as a component of pea-Fusarium solani interaction. Plant Physiol. 66:205-211.

Hancock, J.G. 1972. Changes in cell membrane permeability in sunflower hypocotyls infected with Sclerotinia sclerotiorum. Plant Physiol. 49:358-364.

Heisler, E.G., J. Siciliano, E.E. Stinson, and S.F. Osman. 1980. High performance liquid chromatographic determination of major mycotoxins produced by Alternaria molds. J. Chromatogr. 194:89-94.

Hildenbrand, S. and H. Ninnemann. 1994. Kinetics of phytoalexin accumulation in potato tubers of different genotypes infected with Erwinia carotovora subsp. atroseptica. Physiol. Mol. Plant Pathol. 44:335-347.

Hirsch, P., F.F.W. Eckhardt, and R.J. Palmer, Jr. 1995. Fungi active in weathering of rock and stone monuments. Can. J. Bot. 73:1384-1390.

Ikotun, T. 1984. Production of oxalic acid by Penicillium oxalicum in culture and in infected yam tissue and interaction with macerating enzymes. Mycopathology 88:9 14

Kendra, D.F. and L.A. Hadwiger. 1984. Characterization of the smallest chitosan oligomer that is maximally antifungal to Fusarium solani and elicits pisatin formation in Pisum sativum. Expt. Mycol. 8:276-278.

Kuc, J. 1987. Plant immunization and its applicability for disease control, p. 255-274 In: I. Chet (ed.). Innovative approaches to plant disease control. Wiley, New York.

Margo, P., P. Marciano, and P. Di Lenna. 1984. Oxalic acid production and its role in pathogenesis of Sclerotinia sclerotiorum. FEMS Microbiol. Lett. 24:9-12.

Mauch, F., L.A. Hadwiger, and T. Boller. 1984. Ethylene: Symptom, not signal for the induction of chitinase and B-1,3-glucanase in pea pods by pathogens and elicitors. Plant Physiol. 76:607-610.

Maxwell, D.P.and R.D. Lumsden. 1970. Oxalic acid production by Sclerotinia sclerotiorum in infected bean and in culture. Phytopathology 60:1395-1398.

Miao, V.P.W. and H.D. VanEtten. 1992. Genetic analysis of the role of phytoalexin detoxification in virulence of fungus Nectria haematococca on chickpea (Cicer arietinum). Appl. Environ. Microbiol. 58:809-814.

Osburn, A., P. Bowyer, P. Luness, B. Clark, and M. Daniels. 1995. Fungal pathogens of oat roots and tomato leaves employ closely related enzymes to detoxify different host plant saponins. Mol. Plant Microbe Interact. 8:971-978.

Otani, H., K. Kohmoto, and M. Kodoma. 1995. Alternaria toxins and their effects on host plants. Can. J. Bot. 73(Suppl. 1):453-458.

Pantaleone, D., M. Yalpani, and M. Scollar. 1992. Unusual susceptibility of chitosan to enzymatic hydrolysis. Carbohyd. Res. 237:325-332.

Pearce, G., P.A. Marchand, J. Griswold, M.G. Lewis, and C.A. Ryan. 1998. Accumulation of feruloyltyramine and p-coumaroyltyramine in tomato leaves in response to wounding. Phytochemistry 47:659-664.

Pearson, R.C. and D.H. Hall. 1975. Factors affecting the occurrence and severity of blackmold of ripe tomato fruit caused by Alternaria alternata. Phytopathology 67:1352-1359.

Poovaiah, B.W. 1986. Role of calcium in prolonging storage life of fruits and vegetables. Food Technol. 40:86-89.

Reddy, M.V., J. Arul, E. Ait-Barka, P Angers, C. Richard, and F. Castaigne. 1998 Effect of chitosan on growth and toxin production by Alternaria alternata f.sp lycopersici. Biocontrol Sci. Technol. 8:33-43.

Reddy, M.V., J. Arul, P. Angers, and L. Couture. 1999. Chitosan treatment of wheat seeds induces resistance to Fusarium graminearum and improves seed quality. J. Agr. Food Chem. 47:1208-1216.

Reddy, M.V., A. Asselin, and J. Arul. 1997. Effect of chitosan on tissue maceration and enzyme production by Erwinia carotovora in Potato. HortScience 32:511 (abstr.).

SAS Inst., Inc. 1988. SAS users guide: Statistics. Version 6.03. SAS Inst., Inc., Cary, N.C

Schafer, W. 1994. Molecular mechanisms of fungal pathogenicity to plants. Annu. Rev. Phytopathol. 32:461-477.

Schlösser, E. 1975. Role of saponins in antifungal resistance. III. Tomatine dependent development of fruit rot organisms on tomato fruits. Z. Pfanzen. Pflanzenschutz 83:476-484.

Stack, M.E., P.B. Mislivec, J.A. Roach, and A.E. Polhand. 1985. Liquid chromatographic determination of tenuzonic acid and alternariol methyl ether in tomatoes and tomato products. J. Assn. Offic. Anal. Chem. 68:640-642.

Stinson, E. E., D.D. Bills, S.F. Osman, J. Siciliano, M.J. Ceponis, and E.G. Heisler. 1980. Mycotoxin production by Alternaria species grown on apples, tomatoes, and blueberries. J. Agr. Food Chem. 26:960-963.

Stinson, E.E., S.F. Osman, E.G. Heisler, J. Siciliano, and D.D. Bills. 1981. Mycotoxin production in whole tomatoes, apples, oranges and lemons. J. Agr. Food Chem. 29:790-792.

Swinburne, T.R. 1983. Quiescent infections in post-harvest diseases, p. 1-21. In: C. Dennis (ed.). Postharvest pathology of fruits and vegetables. Academic Press, London.

VanEtten, H. D., D.E. Matthews, and P.S. Matthews. 1989. Phytoalexin detoxification: Importance for pathogenicity and practical considerations. Annu. Rev. Phytopathol. 27:143-164.

Visconti, A., A. Logrieco, and A. Bottalico. 1986. Natural occurrence of Alternaria mycotoxins in olives-Their production and possible transfer into the oil. Food Additives and Contaminants 3:323-330.

Wolf, G.A. and S.J. Wirth. 1989. Application of soluble chromogenic substrates for assays of polysaccharide endohydrolase activity, p. 409-413. In: Z. Klement, K. Rudolph and D.S. Sands (eds.). Methods in phytobacteriology. Publishing House Hungarian Acad. Sci., Budapest, Hungary. 